\title{
Effect of Different Nutrient Management Practices on the Economics of Late Sown Kharif Maize (Zea mays L.) in Western Uttar Pradesh, India
}

\author{
Mohd. Mued ${ }^{1}$, Virendra Singh ${ }^{1}$, Mohd. Meraj Khan ${ }^{2 *}$ and Mubeen ${ }^{3}$ \\ ${ }^{1}$ Department of Agriculture Science and Engineering IFTM University, Moradabad, \\ U.P. 244 102, India \\ ${ }^{2}$ Department of Vegetable Science, Narendra Deva University of Agriculture \& Technology, \\ Kumarganj, Faizabad (U.P.), India \\ ${ }^{3}$ Department of Agriculture, Mohammad Ali Jauhar University, Rampur, Uttar Pradesh, India \\ *Corresponding author
}

\begin{tabular}{|c|c|}
\hline & A B S T R A C T \\
\hline $\begin{array}{l}\text { Ke y w o r d s } \\
\text { Maize, Economics, } \\
\text { B: C ratio and grain } \\
\text { yield. }\end{array}$ & $\begin{array}{l}\text { The field experiment was conducted during kharif season of } 2015 \text {, at the experimental } \\
\text { farm of IFTM University, Lodhipur Rajput, Delhi Road NH-24, Moradabad, Uttar } \\
\text { Pradesh. Thirteen treatment combinations viz., } \mathrm{T}_{1} \text { (Control), } \mathrm{T}_{2}\left(120 \% \text { RDF NPK), } \mathrm{T}_{3}\right. \\
(120 \% \text { RDF NPK }+\mathrm{B}), \mathrm{T}_{4}(120 \% \text { RDF NPK }+\mathrm{Zn}), \mathrm{T}_{5}(120 \% \text { RDF NPK }+\mathrm{B}+\mathrm{Zn}), \mathrm{T}_{6} \\
\left(100 \% \text { RDF NPK), } \mathrm{T}_{7}(100 \% \text { RDF NPK }+\mathrm{B}), \mathrm{T}_{8}(100 \% \text { RDF NPK }+\mathrm{Zn}), \mathrm{T}_{9}(100 \% \text { RDF }\right. \\
\text { NPK }\end{array}$ \\
\hline Article Info & FYM ha $\left.{ }^{-1}\right), T_{12}\left(75 \%\right.$ NPK $\left.+Z n+10 t^{-10 Y M ~ h a ~}{ }^{-1}\right)$, and $T_{13}(75 \%$ RDF NPK $+Z n+B+10 t$ \\
\hline $\begin{array}{l}\text { Accepted: } \\
\text { 26 July } 2017 \\
\text { Available Online: } \\
\text { 10 September } 2017\end{array}$ & $\begin{array}{l}\left.\text { FYM ha }{ }^{-1}\right) \text { with different levels of NPK with and without FYM, Zn and Boron were taken } \\
\text { for this investigation to find out the most economical amongst them. The results revealed } \\
\text { that combined application of } 75 \% \text { NPK }+\mathrm{Zn}+\mathrm{B}+10 \mathrm{t} \text { FYM ha }{ }^{-1} \text { i.e., } \mathrm{T}_{13} \text { recorded higher } \\
\text { grain yield }(26.42 \mathrm{q} / \mathrm{ha}) \text {, gross returns (₹.49595.00), net return }(₹ .30300 .00) \text { and B:C } \\
\text { ratio (1.57) followed by } \mathrm{T}_{12}\left(75 \% \mathrm{RDF} \mathrm{NPK}+\mathrm{Zn}+10 \mathrm{t} \mathrm{FYM} \mathrm{ha}^{-1} \text {. }\right.\end{array}$ \\
\hline
\end{tabular}

\section{Introduction}

Maize (Zea mays L.), crop also; called "queen of cereals" is the third most important crop in India after rice and wheat. Globally, India stands $5^{\text {th }}$ rank in acreage and $8^{\text {th }}$ rank in production of maize. It is cultivated on 9.7 million hectares with a production of 24.3 million tones having productivity of 26.76 quintals ha ${ }^{-1}$ (MOA, 2014). Maize being an exhaustive crop has very high nutrient demand and its productivity mainly depend upon nutrient management system. The use of major nutrients alone fail to sustain yield levels due to increasing deficiency of secondary and micronutrients and alteration in the physical and chemical properties of soil which is unfavorable for crop growth. The present hike in the price of chemical fertilizers has compelled the Indian farmers for an alternative nutrient management system. At the same time only organic manures alone do not produce spectacular increase in the crop yields, due to their low nutrient status and availability in short period and on the other hand dependency on chemical fertilizers alone may not provide a viable economic option. Therefore, to 
maintain soil productivity on a sustainable basis an integrated nutrient management approach, using both organic and inorganic sources of nutrients should be adopted. In the present context, the use of manures must be given prime importance and fertilizer use should be limited to balance the nutrient requirement of the crops. In order to sustain soil fertility and to reap rich harvests of maize, it is imperative that both organic manuring and mineral nutrition have to be given adequate attention under irrigated conditions. Keeping these points in view, the present study was under taken.

\section{Materials and Methods}

The field experiment was conducted during kharif season of 2015, at the experimental farm of IFTM University, Lodhipur Rajput, Delhi Road NH-24, Moradabad, Uttar Pradesh. The district Moradabad lies between $28^{\circ} 21^{\prime}$ to $28^{\circ} 16^{\prime}$ North latitude and $78^{\circ} 4^{\prime}$ to $79^{\circ}$ East longitude above mean sea level of (193.23) meters. The experimental plots have uniform topography with homogenous fertility and soil characteristics typical to suit Maize crop cultivation. The fields were fairly leveled and had good drainage having assured irrigation facility. The soil of the experimental site was sandy loam in texture, having $\mathrm{pH}=$ 7.0- 7.5 with 0.6 per cent of organic carbon. Thirteen treatment combinations viz., $\mathrm{T}_{1}$ (Control), $\mathrm{T}_{2}$ (120\% RDF NPK), $\mathrm{T}_{3}(120 \%$ $\mathrm{RDF} \mathrm{NPK}+\mathrm{B}), \mathrm{T}_{4}(120 \% \mathrm{RDF} \mathrm{NPK}+\mathrm{Zn})$, $\mathrm{T}_{5}(120 \% \mathrm{RDF} \mathrm{NPK}+\mathrm{B}+\mathrm{Zn}), \mathrm{T}_{6}(100 \%$ RDF NPK), $\mathrm{T}_{7}(100 \%$ RDF NPK $+\mathrm{B}), \mathrm{T}_{8}$ $\left(100 \%\right.$ RDF NPK + Zn), $\mathrm{T}_{9}(100 \%$ RDF NPK $+\mathrm{B}+\mathrm{Zn}), \mathrm{T}_{10}(75 \%$ RDF NPK + 10 t FYM $\left.\mathrm{ha}^{-1}\right), \mathrm{T}_{11}(75 \%$ RDF NPK + B + 10 t FYM $\left.\mathrm{ha}^{-1}\right), \mathrm{T}_{12}\left(75 \% \mathrm{NPK}+\mathrm{Zn}+10 \mathrm{t} \mathrm{FYM} \mathrm{ha}^{-1}\right)$, and $\mathrm{T}_{13}(75 \%$ RDF NPK + Zn + B +10 t FYM $\mathrm{ha}^{-1}$ ) with different levels of NPK with and without FYM, $\mathrm{Zn}$ and Boron were taken for this investigation. These treatments were tried by using variety Naveen (hybrid) in Randomized Complete Block Design (RCBD) with three replications. Recommended doses of fertilizer (RDF) NPK (120:60:40 kg ha-1), Zinc $\left(10 \mathrm{~kg} \mathrm{ha}^{-1}\right)$ and Boron $\left(10 \mathrm{~kg} \mathrm{ha}^{-1}\right)$ were applied during kharif maize cultivation. Half doses of nitrogen, full doses of phosphorus, potassium, zinc and boron were applied as basal form. While remaining half dose of nitrogen was applied at teaseling stage according to the treatments. As per the treatments the FYM was applied and incorporated into soil three weeks before sowing and other nutrient sources like N, P, $\mathrm{K}$, B and $\mathrm{Zn}$ were supplied through urea, DAP, MOP, borax and zinc Sulphate, respectively. The seeds were sown at the rate of $20 \mathrm{~kg} \mathrm{ha}^{-1}$ with the spacing of $50 \mathrm{~cm} \mathrm{x}$ $20 \mathrm{~cm}$. Irrigation was given as and when required depending upon soil moisture. The analysis of plant samples were done at harvest for calculating yield and B: $\mathrm{C}$ ratio was calculated by using the formula:

$$
\mathrm{B}: \mathrm{C} \text { ratio }=\frac{\text { Net returns }(\mathrm{Rs} / \mathrm{ha})}{\text { Cost of cultivation }(\mathrm{Rs} / \mathrm{ha})}
$$

\section{Results and Discussion}

Combined application of $75 \%$ of recommended dose of NPK (120:60:40 kg ha $\left.{ }^{1}\right)+\mathrm{Zn} 10 \mathrm{~kg} \mathrm{ha}^{-1}+\mathrm{B} 10 \mathrm{~kg} \mathrm{ha}^{-1}+\mathrm{FYM}_{10 \mathrm{t}}$ $\mathrm{ha}^{-1}$ i.e. $\mathrm{T}_{13}$ was found most remunerative and gave maximum gross returns (19295.00 ₹ $\mathrm{ha}^{-}$ $\left.{ }^{1}\right)$, net returns $\left(30300.00 ₹ \mathrm{ha}^{-1}\right)$ and $\mathrm{B}: \mathrm{C}$ ratio (1.57) followed by $\mathrm{T}_{12}(75 \% \mathrm{RDF} \mathrm{NPK}+\mathrm{Zn}$ + 10 t FYM ha $^{-1}$ ) ₹46138.61 ha ${ }^{-1}$, ₹.27493.61 $\mathrm{ha}^{-1}$ and 1.47 , respectively. This may be due to higher grain yield (26.42 $\mathrm{q} \mathrm{ha}^{-1}$ ) (Table 1). The lower gross returns ( $\left.₹ 25094.58 \mathrm{ha}^{-1}\right)$, net returns ( $\left(₹ 12489.58 \mathrm{ha}^{-1}\right.$ and B: C ratio (0.99) were noticed with the $\mathrm{T}_{1}$ (Control). Similar results observed by Raskar et al., (2013). Highest B: C ratio was found to be significant under application of $160 \mathrm{~kg} \mathrm{~N} \mathrm{ha}^{-1}$, $80 \mathrm{~kg} \mathrm{P}_{2} \mathrm{O}_{5} \mathrm{ha}^{-1}$ and $5 \mathrm{~kg} \mathrm{Zn} \mathrm{ha}{ }^{-1}$, over other treatments (Rao et al., 2013; Ahmad et al., 2013)). 
Table.1 Economics of maize as influenced by different nutrient management practices

\begin{tabular}{|c|c|c|c|c|c|}
\hline Treatments & $\begin{array}{c}\text { Grain yield } \\
\left(\mathrm{q} \mathrm{ha}^{-1}\right)\end{array}$ & $\begin{array}{c}\text { Cost of cultivation } \\
\left(₹ h^{-1}\right)\end{array}$ & $\begin{array}{l}\text { Gross Return } \\
\left(₹ \text { ha }^{-1}\right)\end{array}$ & $\begin{array}{l}\text { Net Return } \\
\left(₹ \text { ha }^{-1}\right)\end{array}$ & $\begin{array}{c}\text { B:C } \\
\text { Ratio }\end{array}$ \\
\hline $\mathrm{T}_{1}$ (Control) & 15.01 & 12605.00 & 25094.58 & 12489.58 & 0.99 \\
\hline $\mathrm{T}_{2}(120 \%$ RDF NPK $)$ & 18.31 & 17460.00 & 35724.28 & 18264.28 & 1.05 \\
\hline $\mathrm{T}_{3}(120 \%$ RDF NPK + B $)$ & 16.43 & 18110.00 & 36658.47 & 18548.47 & 1.02 \\
\hline $\mathrm{T}_{4}(120 \%$ RDF NPK $+\mathrm{Zn}$ & 21.51 & 17790.00 & 41374.03 & 23584.03 & 1.33 \\
\hline $\mathrm{T}_{5}(120 \%$ RDF NPK + B + Zn) & 23.84 & 18440.00 & 45158.89 & 26718.89 & 1.45 \\
\hline $\mathrm{T}_{6}(100 \% \mathrm{RDF}$ NPK $)$ & 19.99 & 16516.00 & 39178.89 & 22662.89 & 1.37 \\
\hline $\mathrm{T}_{7}(100 \%$ RDF NPK + B $)$ & 20.14 & 17166.00 & 39076.53 & 21910.53 & 1.28 \\
\hline $\mathrm{T}_{8}(100 \% \mathrm{RDF} \mathrm{NPK}+\mathrm{Zn})$ & 20.94 & 16846.00 & 40269.31 & 23423.31 & 1.39 \\
\hline $\mathrm{T}_{9}(100 \%$ RDF NPK + B+ Zn) & 21.47 & 17496.00 & 41778.89 & 24282.89 & 1.39 \\
\hline $\mathrm{T}_{10}\left(75 \% \mathrm{NPK}+10 \mathrm{t} \mathrm{FYM} \mathrm{ha}^{-1}\right)$ & 22.14 & 18315.00 & 43493.61 & 25178.61 & 1.37 \\
\hline $\mathrm{T}_{11}\left(75 \% \mathrm{NPK}+\mathrm{B}+10 \mathrm{t} \mathrm{FYM} \mathrm{ha}^{-1}\right)$ & 23.03 & 18965.00 & 44722.92 & 25757.92 & 1.36 \\
\hline $\mathrm{T}_{12}\left(75 \% \mathrm{NPK}+\mathrm{Zn}+10 \mathrm{t} \mathrm{FYM} \mathrm{ha}^{-1}\right)$ & 24.28 & 18645.00 & 46138.61 & 27493.61 & 1.47 \\
\hline $\mathrm{T}_{13}\left(75 \% \mathrm{NPK}+\mathrm{Zn}+\mathrm{B}+10 \mathrm{t} \mathrm{FYM} \mathrm{ha}^{-1}\right)$ & 26.42 & 19295.00 & 49595.00 & 30300.00 & 1.57 \\
\hline
\end{tabular}

Yadav et al., (2016) also showed that growth, yield attributes, maize equivalent yield, net return and $\mathrm{B}: \mathrm{C}$ ratio were significantly higher in treatment $5 \mathrm{t} \mathrm{ha}^{-1}$ Vermicompost $+75 \%$ recommended dose of NPK over other treatments. It gave grain yield $\left(4.77 \mathrm{t} \mathrm{ha}^{-1}\right)$, maize equivalent yield $\left(6.06 \mathrm{t} \mathrm{ha}^{-1}\right)$, net return (₹. $26273 \mathrm{ha}^{-1}$ ) and B: C ratio (0.85) over other treatments.

\section{References}

Ahmad, W., Shah Z., Khan F., Ali S and Malik W. 2013. Maize yield and soil properties as influenced by integrated use of organic inorganic and bio fertilizers in low fertility soil. Soil environs, 32: pp 121-129.

MOA, 2014. Directorate of Economics and Statistics, Ministry of Agriculture, GOI. htpp://dacnet.in/
Rao P. Venkata, Subbaiah $G$ and Veeraraghavaiah R. 2013. Agronomic responses of Maize to plant population and nitrogen availability. International Journal of Plant Animal and Environmental Science Vol issue (1): pp 107.

Raskar, S.S., Sonani V.V and Patil P.A. 2013. Study of Economics of Maize as influenced by different levels of Nitrogen, Phosphorus and Zinc. International Journal of Scientific and Research Publications 3(10): pp 31.

Yadav Ajay Kumar, Chand Subash and Thenua O.V.S. 2016. Effect of integrated nutrient management on productivity of Maize with mungbean inter cropping. G. J. B. B. 5(1): pp 115118.

\section{How to cite this article:}

Mohd. Mued, Virendra Singh, Mohd. Meraj Khan and Mubeen. 2017. Effect of Different Nutrient Management Practices on the Economics of Late Sown Kharif Maize (Zea mays L.) in Western Uttar Pradesh, India. Int.J.Curr.Microbiol.App.Sci. 6(9): 2455-2457. doi: https://doi.org/10.20546/ijcmas.2017.609.302 